\title{
PERANCANGAN SISTEM APLIKASI PENGADAAN BARANG PADA BALAI BESAR KIMIA DAN KEMASAN
}

\author{
Siti Jamiul Khowais', Nur Alamsyah ${ }^{2}$ \\ ${ }^{1,2}$ Universitas Indraprasta PGRI \\ Jl. Raya Tengah No. 80, Kel. Gedong, Kec. Pasar Rebo, Jakarta Timur 13760, Jakarta \\ 15itijamiulk@gmail.com, ${ }^{2}$ alamcbr11@gmail.com
}

\begin{abstract}
ABSTRAK
Pengadaan Barang untuk persediaan dibutuhkan dalam kegiatan perusahaan. Persediaan barang merupakan bahan atau barang yang disimpan untuk digunakan memenuhi kebutuhan tertentu, misalkan digunakan untuk proses produksi maupun kegiatan perkantoran sehari-hari. Salah satu faktor yang mempengaruhi keberhasilan perusahaan adalah persediaan barang. Tujuan dari penelitian yaitu untuk menghasilkan sebuah sistem aplikasi pengadaan barang yang nantinya akan digunakan oleh pihak Balai Besar Kimia dan Kemasan untuk membantu dan mempermudah pegawai dan petugas gudang dalam melakukan proses input data pengajuan permintaan barang, pendataan persediaan barang, serta pembuatan laporan sehingga dapat meningkatkan efisiensi pekerjaan. Metode penelitian yang penulis gunakan adalah metode research and development. Suatu metode penelitian yang dilakukan secara sengaja, sistematis, untuk menemukan, dan memperbaiki, untuk pengembangan produk dan menciptakan suatu produk baru melalui pengujian keefektifan, sehingga produk tersebut dapat dipertanggungjawabkan. Hasil dari penelitian yaitu suatu aplikasi yang dibuat dengan menggunakan bahasa pemrograman Java NetBeans dan MySQL digunakan sebagai penyimpanan data. Membangun sistem ini, menggunakan alat bantu berupa Diagram Aliran Data (DAD) Konteks, Nol dan Rinci. Kata Kunci: Pengadaan Barang, Java, MySQL, Sistem Aplikasi.
\end{abstract}

\begin{abstract}
Procurement of goods for inventory needed in company activities. Inventories of goods are materials or goods that are stored for use to meet certain needs, for example used for the production process or daily office activities. One of the factors that influence the company's success is inventory. The purpose of the research is to produce an application system for procurement of goods which will later be used by the Center for Chemistry and Packaging to assist and facilitate warehouse employees and officers in the process of inputting data for submitting requests for goods, collecting inventory data, and making reports so as to increase efficiency. profession. The research method that the author uses is the research and development method. A research method that is carried out intentionally, systematically, to find, and improve, for product development and creating a new product through effectiveness testing, so that the product can be accounted for. The result of the research is an application created using the Java NetBeans programming language and MySQL is used as data storage. Building this system, using tools in the form of Context, Zero and Detailed Data Flow Diagrams (DAD).
\end{abstract}

Key Word: Procurement of Goods, Java, MySQL, Application System.

\section{PENDAHULUAN}

Semakin pesatnya perkembangan ilmu pengetahuan dan teknologi yang berpengaruh terhadap kemajuan bisnis, baik secara individual, maupun secara instansi.

Berkembangnya media informasi memiliki peranan penting dalam suatu usaha untuk menciptakan kemajuan yang diperuntukan bagi kepentingan manusia di semua bidang.

Persediaan barang merupakan bahan atau barang yang disimpan untuk digunakan memenuhi kebutuhan tertentu, misalkan digunakan untuk proses produksi maupun kegiatan perkantoran sehari-hari. Sejalan dengan hal tersebut sangat diperlukan adanya sistem informatika pengolah data sehingga pekerjaan menjadi efektif dan efisien.

Balai Besar Kimia dan Kemasan memiliki tugas melaksanakan kegiatan penelitian, pengembangan, kerjasama, standardisasi, pengujian, sertifikasi, kalibrasi, dan pengembangan kompetensi industri kimia dan kemasan memiliki kebutuhan barang yang diperlukan untuk melaksanakan tugas dan fungsinya tersebut, dimana barang atau bahan yang dibutuhkan seperti bahan kimia, bahan non kimia, alat tulis kantor, keperluan peralatan rumah tangga, dll. Proses pengolahan data persediaan barang Pada Balai 
Besar Kimia dan Kemasan menggunakan sistem konvensional yaitu melakukan pencatatan stok persediaan dan mutasi keluar masuknya barang di dalam sebuah kartu stok. Karena sistem konvensional tersebut sering mengalami masalah dalam pencatatan stok persediaan dimana terdapat perbedaan jumlah data barang yang terdapat pada kartu stok dengan stok fisik barang atau bahan yang ada pada gudang. Oleh sebab itu, dibutuhkan suatu sistem untuk menanggulangi permasalahan tersebut dengan melakukan perbaikan pada pengolahan data.

Tujuan penelitian ini yaitu untuk menghasilkan sebuah sistem aplikasi pengadaan barang yang nantinya akan digunakan oleh pihak Balai Besar Kimia dan Kemasan.

Perancangan sistem atau desain sistem yaitu mendesain solusi sistem yang telah dikonsep pada saat menganalisis sistem berdasarkan kebutuhan dan permasalahan sistem, sehingga sistem dapat diterapkan menggunakan teknologi komputerisasi (Sri, 2016).

Perancangan sistem bertujuan untuk memenuhi kebutuhan pengguna sistem serta memberikan gambaran jelas dan menghasilkan rancang bangun yang lengkap.

Pengertian sistem menurut (Jeperson, 2014), Sistem adalah suatu jaringan kerja dari prosedur-prosedur yang saling berhubungan, berkumpul bersama-sama untuk melakukan kegiatan atau untuk melakukan sasaran yang tertentu.

Menurut (Jeperson, 2014), Informasi adalah data yang diolah menjadi bentuk yang lebih berguna dan lebih berarti bagi penerimanya. Sumber informasi adalah data. Data kenyataan yang menggambarkan suatu kejadian - kejadian dan kesatuan nyata. Menurut (Tata, 2012), Sistem informasi adalah suatu sistem di dalam suatu organisasi yang mempertemukan kebutuhan pengolahan transaksi harian yang mendukung fungsi operasi organisasi yang bersifat manajerial dengan kegiatan strategi dari suatu organisasi untuk dapat menyediakan kepada pihak luar tertentu dengan laporan-laporan yang diperlukan.
Menurut (Nazruddin, 2012), Perangkat Lunak Aplikasi adalah suatu sub kelas perangkat lunak komputer yang memanfaatkan kemampuan komputer langsung untuk melakukan suatu tugas yang diinginkan pengguna. Biasanya

perangkat lunak aplikasi dibandingkan dengan perangkat lunak sistem yang mengintegrasikan berbagai kemampuan komputer, tapi tidak secara langsung menerapkan kemampuan tersebut untuk mengerjakan suatu tugas yang menguntungkan pengguna.

Pengadaan barang dan jasa identik dengan adanya berbagai fasilitas baru, berbagai bangunan, jalan, rumah sakit, gedung perkantoran, alat tulis yang dilaksanakan disebuah instansi pemerintah. Pengadaan barang dan jasa sering disebut tender ini sebenarnya bukan hanya terjadi di instansi pemerintah. Pengadaan barang dan jasa bisa terjadi di BUMN dan perusahaan swasta Nasional maupun Internaisonal. Intinya pengadaan barang dan jasa dibuat untuk memenuhi kebutuhan perusahaan atau instansi pemerintah akan barang dan jasa yang dapat menunjang kinerja dan performance mereka (Nur \& Jenny, 2017).

Netbeans merupakan sebuah aplikasi Integrated Development Environment (IDE) yang Menggunakan Bahasa Pemograman Java dari Sun Microsystems yang berjalan diatas swing (Nofriadi, 2015).

Menurut (Rosa \& M., 2018), mengungkapkan bahwa Java merupakan bahasa pemrograman yang paling konsisten dalam mengimplementasikan paradigma pemrograman berorientasi objek. Menurut (Abdul, 2013), mengungkapkan bahwa Bahasa pemrograman Java adalah bahasa yang bersifat multiplatform, mengingat bahasa ini dapat digunakan di berbagai platform, dari windows hingga linux.

Menurut (Kartini et al., 2013), berpendapat bahwa XAMPP merupakan tool yang menyediakan paket perangkat lunak dalam satu buah paket. Menurut (Irmayani, 2019), Data Flow Diagram atau dalam bahasa Indonesia menjadi Diagram Alir Data (DAD) adalah refresentasi grafik yang menggambarkan aliran informasi dan transformasi informasi yang diaplikasikan 
sebagai data yang mengatur dari masukan (input) dan keluaran (output). DFD tidak sesuai untuk memodelkan sistem yang menggunakan pemograman berorientasi objek."

\section{METODE PENELITIAN}

Metode penelitian yang digunakan oleh penulis adalah metode research and development yaitu suatu metode penelitian yang dilakukan secara sengaja, sistematis, untuk menemukan, dan memperbaiki, untuk menyempurnakan produk maupun mengembangkan suatu produk baru melalui pengujian keefektifan, sehingga produk tersebut dapat dipertanggungjawabkan.

Metode yang digunakan dalam pengumpulan data pada penelitian ini diantaranya :

\section{Studi Kepustakaan (Library Research)}

Tahap ini merupakan tahap awal pengumpulan data dari sumber-sumber seperti buku, jurnal, yang berhubungan dengan masalah yang sedang dianalisis. Studi pustaka yang dilakukan berkaitan dengan analisi dan desain sistem informasi, pendataan barang, pemrograman Java dan query MySQL.

\section{Wawancara}

Pada tahap ini peneliti melakukan wawancara dengan kepala bagian tata usaha untuk memperoleh alur sistem serta data-data yang peneliti butuhkan.

Observasi

Tahap ini merupakan tahap melakukan pengamatan langsung terhadap pengguna sistem dan pengamatan langsung terhadap sistem yang sedang berjalan di Balai Besar Kimia dan Kemasan.

Penelitian dilakukan di Balai Besar Kimia dan Kemasan yang beralamat di Jl. Balai Kimia No.1, RT.7/RW.9, Pekayon, Kecamatan Pasar Rebo, Kota Jakarta Timur, Daerah Khusus Ibukota Jakarta 13710 selama 4 bulan dimulai pada bulan Mei tahun 2021 sampai dengan bulan Agustus tahun 2021.

\section{HASIL DAN PEMBAHASAN}

Setelah diamati, ada beberapa masalah yang sering muncul, permasalahan tersebut adalah sebagai berikut:

1. Pengelolaan data pengadaan persediaan barang atau bahan pada Balai Besar Kimia dan Kemasan masih mengalami banyak kesalahan karena masih dilakukan secara manual.
2. Sulitnya dalam mencari kartu stok pada saat mutasi keluar masuknya barang atau bahan karena terlalu banyaknya arsip dan harus membuka arsip kartu stok satu per satu dari masing-masing barang atau bahan karena tidak bisa melakukan pencarian secara otomatis.

3. Pihak yang bertugas tidak dapat memantau jumlah stok barang atau bahan dengan cepat karena terlebih dahulu harus membuka setiap arsip kartu stok yang ada untuk disamakan datanya dengan stok fisik barang.

4. Belum adanya rancangan sistem seperti permintaan barang atau bahan, penyerahan barang atau bahan dan laporan stok barang atau bahan untuk mempermudah karyawan dalam proses transaksi pengadaan barang pada Balai Besar Kimia dan Kemasan.

Kegunaan penelitian bagi instansi:

1. Dengan adanya sistem aplikasi pengadaan barang diharapkan dapat mempermudah pekerjaan dalam pengadaan barang Pada Balai Besar Kimia dan Kemasan.

2. Dengan adanya sistem aplikasi pengadaan barang ini membuat petugas gudang pada Balai Besar Kimia dan Kemasan dapat dengan mudah membuat laporan pada setiap transaksi pada aplikasi.

\section{Diagram Konteks Sistem yang Diusulkan}

Berikut adalah gambaran sistem yang diusulkan untuk Balai Besar Kimia dan Kemasan :

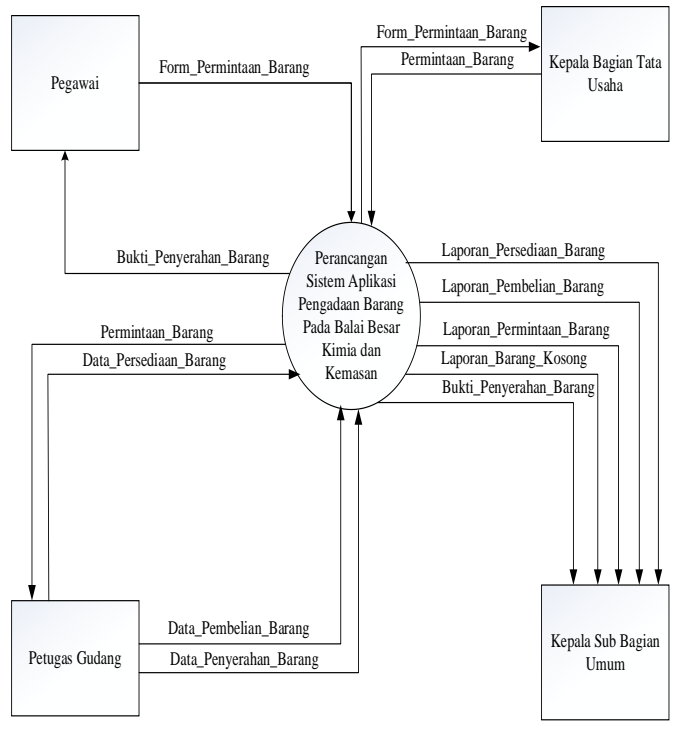

Gambar 1. Diagram Konteks Sistem yang Diusulkan 


\section{Diagram Nol Sistem}

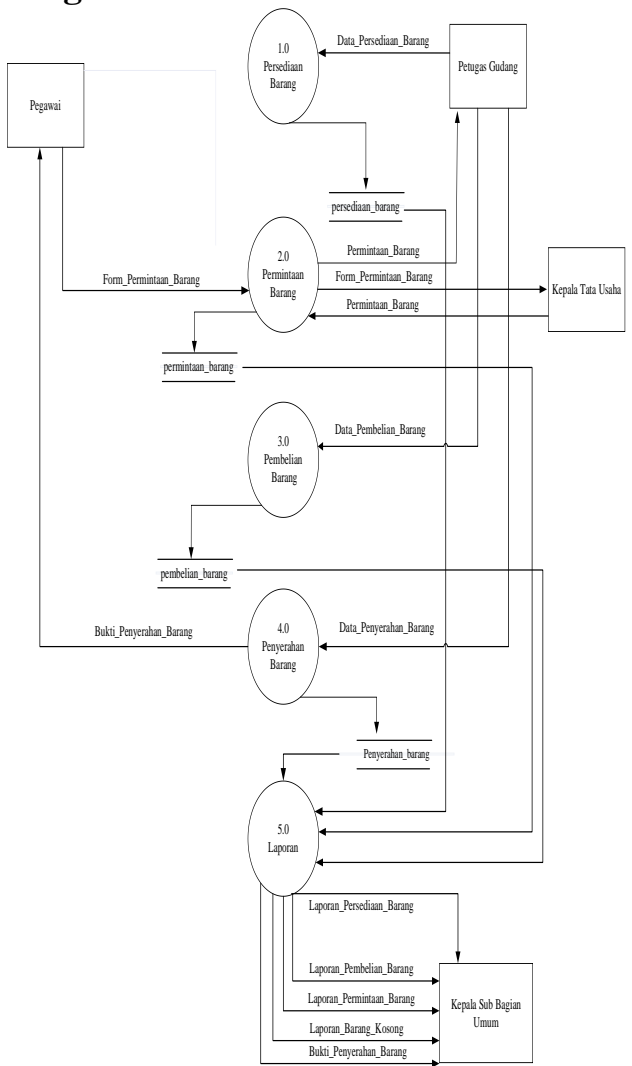

Gambar 2. Diagram Nol Sistem yang Diusulkan

\section{Entity Relationship Diagram (ERD)}

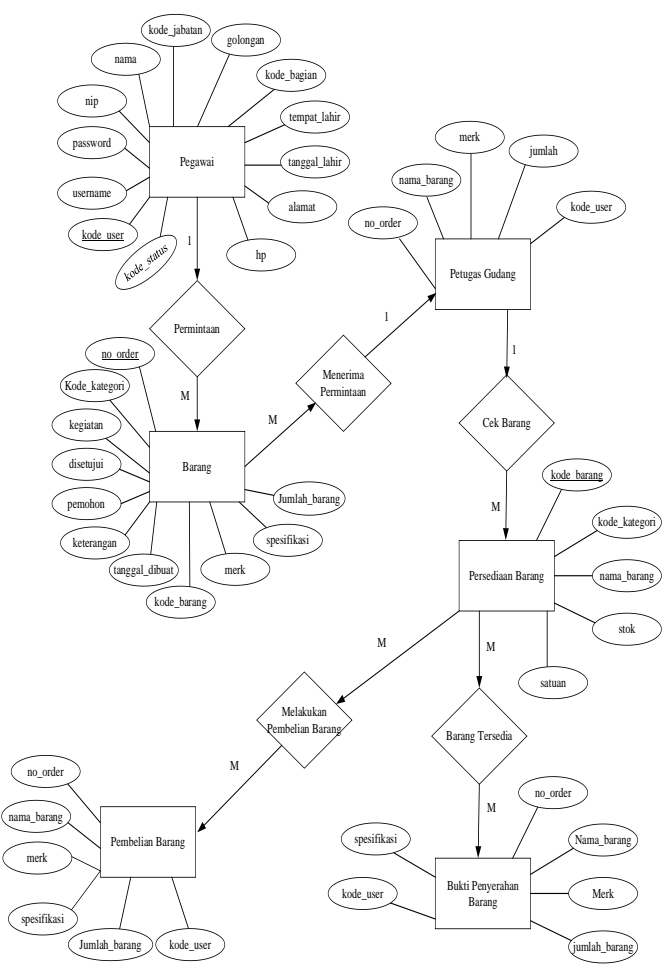

Gambar 3. Entity Relationship Diagram (ERD)

\section{Normalisasi Tahap Pertama (1NF)}

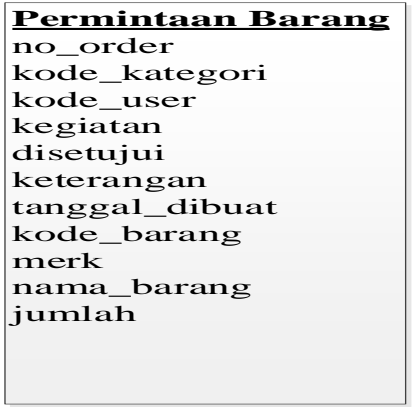

Gambar 4. Bentuk Normalisasi Pertama (1 NF)

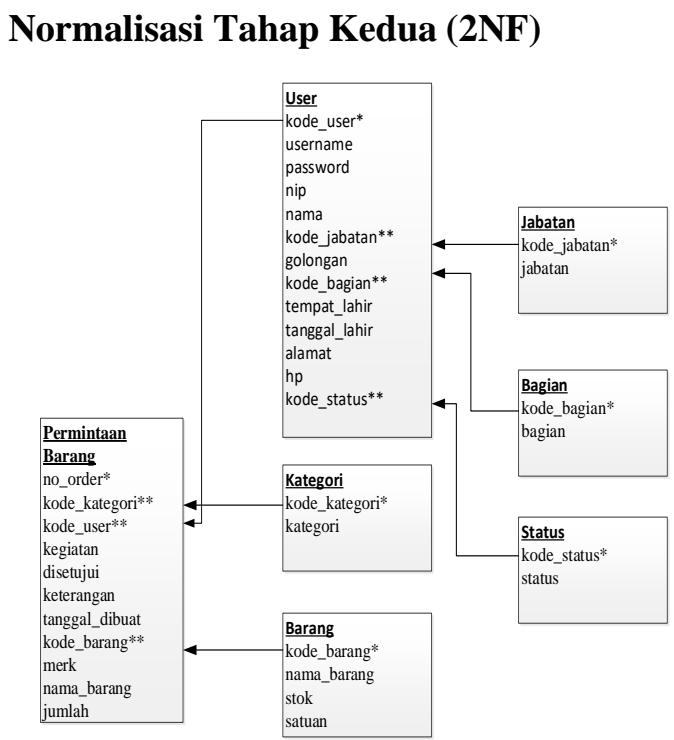

Gambar 5. Bentuk Normalisasi Kedua (2 NF)

\section{Tampilan Menu Login}

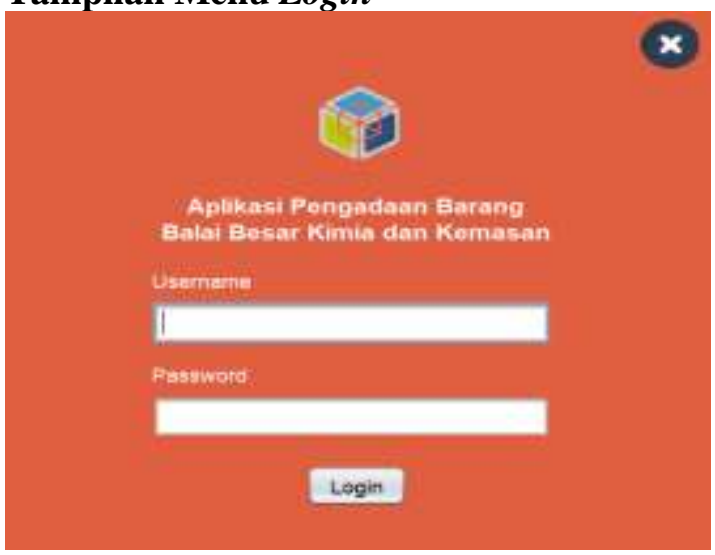

Gambar 6. Tampilan Menu Login

Tampilan login akan muncul pada awal mulai membuka aplikasi, pada proses ini masukan username dan password. Dalam aplikasi ini terdapat beberapa jenis hak akses yaitu hak akses pegawai, hak akses validator, hak akses petugas gudang dan hak akses admin. 


\section{Tampilan Halaman Utama pegawai}

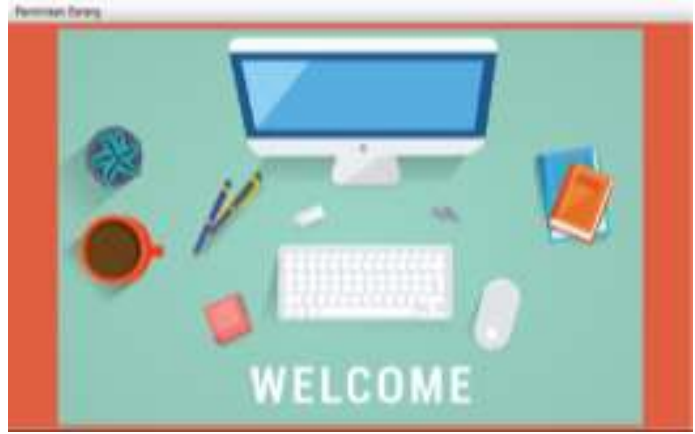

Gambar 6. Tampilan Halaman Utama Pengguna

Tampilan halaman utama pegawai terdapat menu permintaan digunakan menginput data permintaan barang.

\section{Tampilan Halaman Utama Validator}

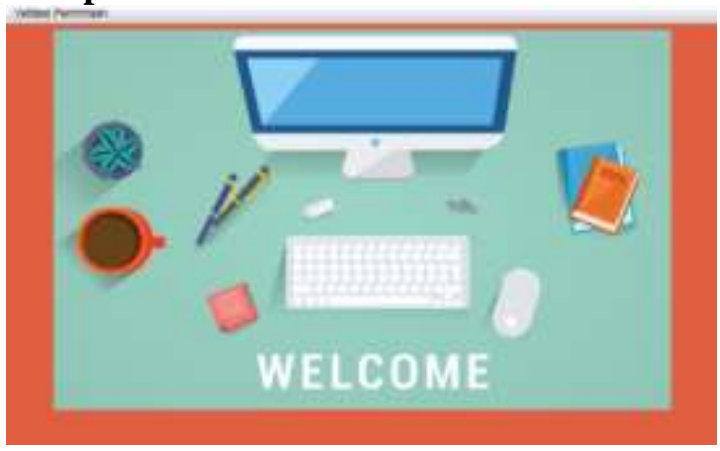

Gambar 7. Tampilan Halaman Utama Validator

Tampilan halaman utama validator terdapat menu validasi permintaan digunakan menyetujui permintaan barang yang telah diinput oleh pegawai.

\section{Tampilan Halaman Utama Petugas Gudang}

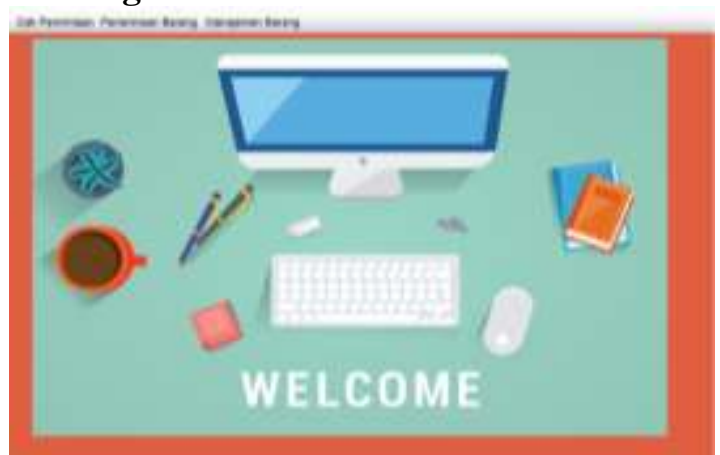

Gambar 8. Tampilan Halaman Utama Petugas Gudang

Tampilan halaman utama petugas gudang terdapat menu cek permintaan yang digunakan untuk melihat permintaan barang yang diinput oleh pegawai kemudian melakukan pengecekan ketersediaan stok barang, lalu terdapat menu penerimaan barang yang digunakan untuk melakukan penyerahan barang yang telah diminta oleh pengguna, dan terdapat menu manajemen barang yang digunakan untuk menginput ketersediaan barang.

\section{Tampilan Halaman Utama Administrator}

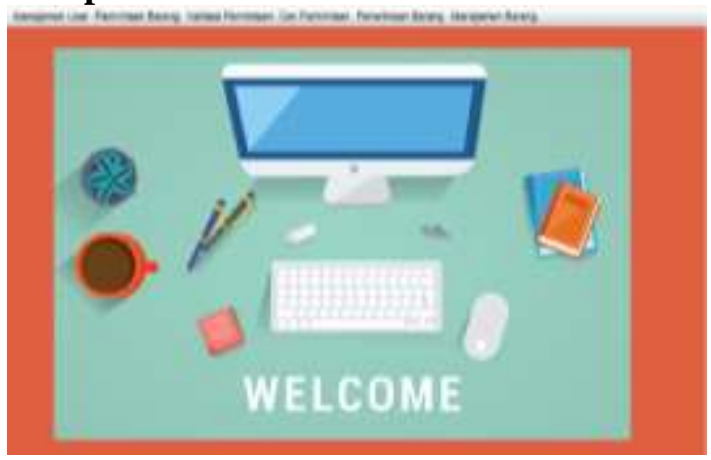

Gambar 9. Tampilan Halaman Utama Administrator

Tampilan halaman utama administrator terdapat keseluruhan menu yang ada pada aplikasi pengadaan barang.

\section{Tampilan Menu Permintaan Barang}

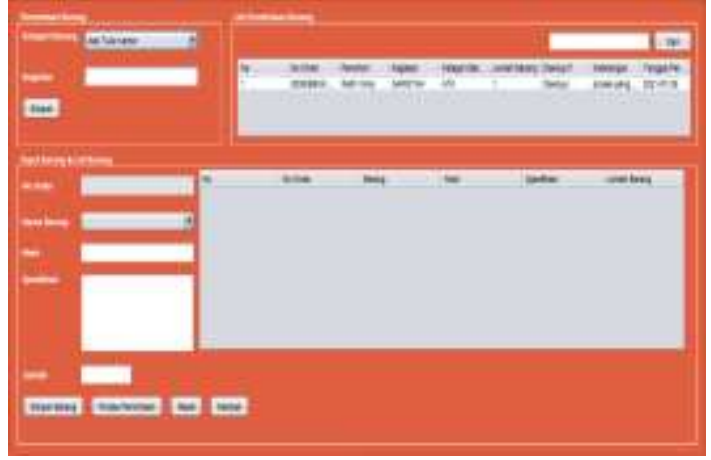

Gambar 11. Tampilan Menu Permintaan Barang

Menu permintaan barang digunakan untuk melakukan penginputan permintaan barang.

Tampilan Menu Validasi Permintaan Barang

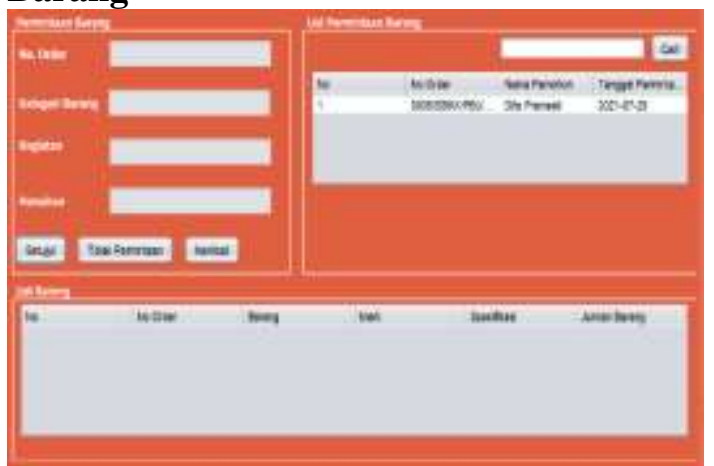

Gambar 12. Tampilan Menu Validasi Permintaan Barang 
Menu validasi permintaan barang digunakan untuk melakukan validasi atau persetujuan permintaan barang yang dilakukan oleh $\mathbf{1}$ pegawai.

\section{Tampilan Menu Cek Permintaan Barang}

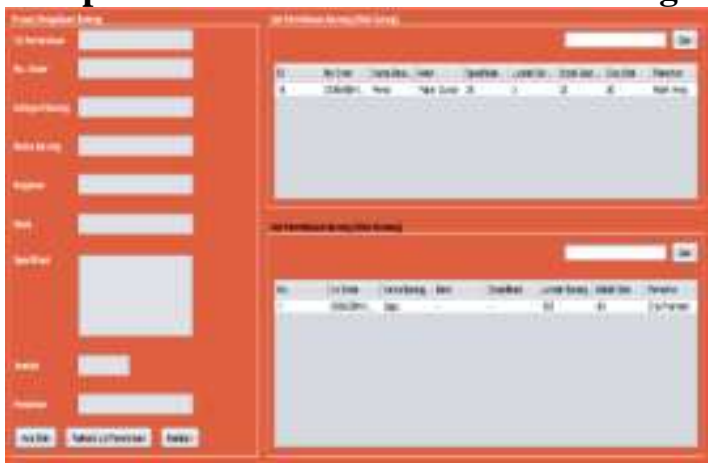

Gambar 13. Tampilan Menu Cek Permintaan Barang

Menu cek permintaan barang digunakan untuk melihat permintaan barang yang diinput oleh pegawai kemudian melakukan pengecekan ketersediaan stok barang.

\section{Tampilan Menu Penerimaan Barang}

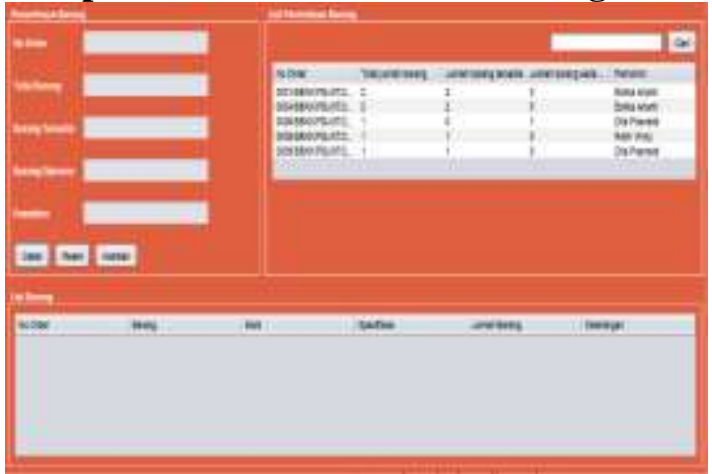

Gambar 14. Tampilan Menu Penerimaan Barang

Menu penerimaan barang digunakan untuk melakukan penyerahan barang yang telah diminta oleh pegawai.

\section{Tampilan Menu Manajemen Barang}

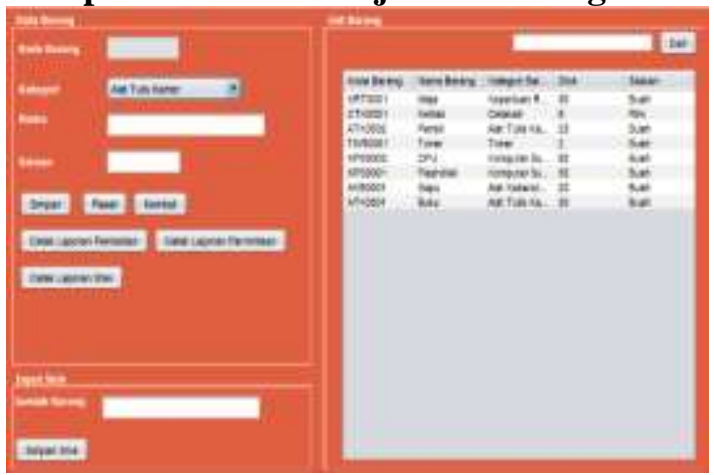

Gambar 15. Tampilan Menu Manajemen Barang
Menu manajemen barang digunakan untuk menginput ketersediaan barang.

\section{Tampilan Laporan Persediaan Barang}

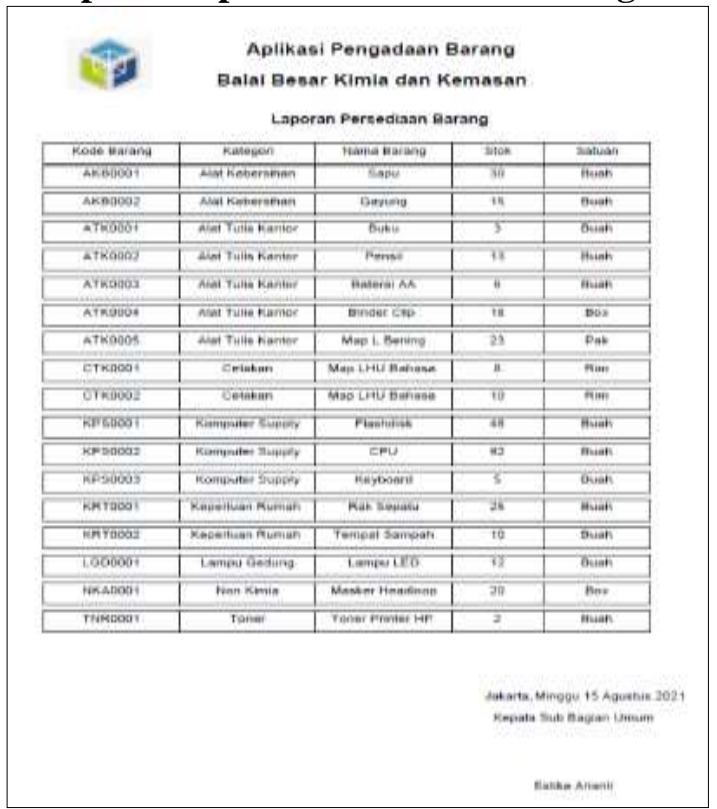

Gambar 16. Tampilan Laporan Persediaan Barang

\section{SIMPULAN DAN SARAN}

Dengan dibuatnya aplikasi pengadaan barang pada Balai Besar Kimia dan Kemasan, diharapkan kegiatan yang berhubungan dengan permintaan barang, persediaan barang dan pengelolaan laporan dapat berjalan dengan baik dan lancar.

Pada aplikasi ini, pegawai dapat melakukan permintaan barang dengan mudah dan petugas gudang melakukan penginputan data-data persediaan barang dan pengelolaan laporan barang dengan cepat dan akurat serta dapat di update dengan mudah.

Penulis mempunyai kesimpulan dengan menggunakan sistem ini berdasarkan perumusan masalah sebagai berikut: Rancangan Sistem Aplikasi Pengadaan Barang pada Balai Besar Kimia dan Kemasan dapat berjalan lebih efektif, cepat, dan mudah dalam pengolahan datanya. Uji coba terhadap perancangan aplikasi ini pada Balai Besar Kimia dan Kemasan saat ini masih dalam proses pelatihan.

Sejalan dengan sistem yang penulis buat, maka demi tercapainya tujuan dan sasaran yang diharapkan, maka penulis dapat memberi saran sebagai berikut: 
Rancangan Sistem Aplikasi Pengadaan Barang Pada Balai Besar Kimia dan Kemasan dapat dikembangkan kembali dalam hal design atau penambahan database sesuai kebutuhan data pada Balai Besar Kimia dan Kemasan. Rancangan Perancangan Sistem Aplikasi Pengadaan Barang Pada Balai Besar Kimia dan Kemasan haruslah didukung oleh sistem yang disiplin dan peraturan yang baik sesuai ketepatan bersama agar dapat berjalan dengan semestinya. Adanya Sistem Aplikasi Pengadaan Barang Pada Balai Besar Kimia dan Kemasan ini diharapkan mampu memberikan manfaat bagi perusahaan.

\section{DAFTAR PUSTAKA}

Abdul, K. (2013). Buku Pintar Programer Pemula Php. Mediakom.

Irmayani. (2019). Jurnal Evolusi. Jurnal Evolusi, $\quad 7, \quad 6$. Https://Repository.Bsi.Ac.Id/Index.Php/ Unduh/Item/228916/Jurnal-Evolusi2019.Pdf

Jeperson, H. (2014). Konsep Sistem Informasi. Cv Budi Utama.

Kartini, Budi, F. U., \& Dewi, P. (2013). Perancangan Sistem Informasi
Pemesanan Tiket Konser Musik Online Berbasis Lokasi. Perancangan Sistem Informasi Pemesanan Tiket Konser Musik Online Berbasis Lokasi, 1, 26. Https://Ojs.Amikom.Ac.Id/Index.Php/Se mnasteknomedia/Article/View/649

Nazruddin, S. (2012). Pemrograman Aplikasi Mobile Smartphone Dan Tablet Pc Berbasis Android. Informatika.

Nofriadi. (2015). Java Fundamental Dengan Netbeans 8.0.2. Deepublish.

Nur, F. I., \& Jenny, M. (2017). Analisis Sistem Pengadaan Barang Dan Jasa (Penunjung Langsung) Pada Di Dinas Pekerjaan Umum Dan Penataan Ruang Kota Manado. Analisis Sistem Pengadaan Barang Dan Jasa (Penunjung Langsung) Pada Di Dinas Pekerjaan Umum Dan Penataan Ruang Kota Manado. Https://Ejournal.Unsrat.Ac.Id/Index.Php /Gc/Article/View/18613/18133

Rosa, S. ., \& M., S. (2018). Rekayasa Perangkat Lunak Terstruktur Dan Berorientasi Objek. Informatika.

Sri, M. (2016). Metode Analisis Dan Perancangan Sistem. Abdi Sistematika. Tata, S. (2012). Analisis Sistem Informasi. 